\title{
The Comparison of Product and Corporate Branding Strategy: a conceptual framework
}

\author{
Alireza Alizadeh ${ }^{1}$, Asghar moshabaki ${ }^{2}$, Seyyed Hamid Khodadad Hoseini ${ }^{3}$, \\ Asadolla Kord Naiej ${ }^{4}$ \\ ${ }^{I}$ Ph.D student of International Marketing, Tarbiat Modares University, Iran \\ ${ }^{2}$ Professor of International Marketing, Tarbiat Modares University, Iran \\ ${ }^{3,4}$ Associate Professor of International Marketing, Tarbiat Modares University, Iran
}

\begin{abstract}
Brand has been a part of almost every company, especially a big one that exists nowadays. Managers need to carefully consider the customer and other stakeholder meanings associated with their branding efforts to make appropriate marketing decisions. Today in competitive world, brand is considered one of the strategic organizational assets. Management of this valuable asset need to strategic thinking and position it in the whole of organization. Therefore, organizations must decide about product or corporate branding.

Submit of comparison table of differences between corporate and product branding strategy and conceptual model of branding strategy choice by multi business firms from developed economies entering to emerging or developing markets is the main participation of this paper. In the others sections of this paper, we address branding, product and corporate branding, synergies between product and corporate branding, similarities and differences between corporate and product branding, branding functions and branding strategy.
\end{abstract}

Keywords: Branding, Product Branding, Corporate Branding, Branding Strategy, Multi Business, Emerging Economy

\section{Introduction}

The role of branding and brand management is primarily to create differentiation and preference in the minds of audiences. The study of branding has traditionally been dominated by an emphasis on product brands. However, the fast innovation, increased service levels and diminishing brand loyalty characterizing today's marketplaces have led to corporate branding becoming a strategic marketing tool (Xie and Boggs, 2006). Ward and Lee (2000) found that there was a shift by firms away from reliance on product brands to reliance on corporate and service brands. Firms must therefore decide whether to build the product brands or the corporate identity.

A successful brand can be defined an identifiable product, service, person or place augmented in such a way that the buyer or user perceives relevant, unique added values which match their needs most closely. Its success results from being able to sustain these added values against competitors. Thus names on many products and services do not prevent them from being commodities which are characterized by the lack of perceived differentiation by customers between competing offerings. Products like milk, tin, iron ore and potatoes come to mind, where purchase decisions tend to be taken on the basis of price or availability and not on the basis of the brand or the manufacturers' name (McDonald et al., 2001).

Conceptually, branding appears to be a necessary means of building sales by identifying products and services. Branding is the initial means to build consumer awareness by naming the offer, but also by distinguishing the offer from other similar products or services within an established category. Branding is about being different (Kay, 2006). Increasingly, the marketing literature suggests that brands are social or cultural "property" (rather than company property) to the extent that consumers in corporate elements of "brand meaning" into their lives. Managers need to carefully consider the customer and other stakeholder meanings associated with their branding efforts to make appropriate marketing decisions. The attempt by managers at Coke to alter their formula in the 1980s, and the profound negative reactions that resulted from this effort, gives credibility to this view. Certainly "power" brands have to be managed with extraordinary care (Kay, 2006).

Brand identity is a unique set of brand associations that the brand strategist aspires to create or maintain, it comes from the organization, whereas brand image is how a brand is perceived by consumers, it has its origin in the minds of consumers. Images are the interpretation of their beliefs and values (Malik et al., 2012). Brand has been a part of almost every company, especially a big one that exists nowadays. It is a statement, an image, a message, which packed and delivered to the customer, so that they know what the company stands for. It is vital to be different in the crowded market so that the brand will not easily forgotten by the customer (Handaria and Iskandar, 2012). 
It is obvious that a brand is not built through creative logos or other symbolic features, it is built through the experience people have with a certain product and the way the individual institution deals with external perceptions. This means that building a brand is a process of translation between external constituencies and internal ambitions, and not a process managed only by marketing or advertising experts. It also means that branding is very much a strategic process with a potentially deep impact on culture and identity, and a process in which fundamental questions, such as "Who are we?" or "Who do we want to be?" are addressed (Stensaker, 2007). The assumption for creating a corporate brand is that a corporate brand will support all aspects of the firm and differentiate the firm from its competitors (Harris and de Chernatony, 2001).

\section{A. Branding}

\section{Literature Review}

Initially, brands were used as the means for differentiating the products by craftsmen and claiming the ownership of animals by cattle owners. Nowadays, companies use brands not only with an aim to differentiate the company's marketing offerings from the ones of competitors, but also to reach the minds and hearts of their customers and create special emotional connections with them. Today, companies in a variety of industries attempt to develop strong brands and to use them for achieving success in the competitive marketing environment (Biedenbach, 2012).

Over recent decades, the branding construct has moved beyond a primary concern with products and services and, since the mid-1990s, focused on organizations in their totality. Subsequent to these developments, a distinct literature has developed around the corporate branding concept. A broader understanding of brands has led to the realization that different branding types require different approaches in terms of their management and this is especially so for corporate brands (Balmer and Thomson, 2009).A brand is a combination of corporate behavior and values, the technical functionality and quality of products and the intangible promise the company instills in their products for customers. It is a combination of tangible and intangible attributes and seeks to create a positive connection with the customer in order to create incentive for customers to use the products of the company in the now and in the future. The brand is the central building block of everything that an organization does. It is the guideline for all corporate behavior, whether it is external or internal (Ropo, 2009).

Companies are trying to influence consumers into buying their product instead of their competitors' products. To do so, they need to differentiate themselves. They need to convince the customers that their product offers a higher value. For instance Coca-Cola does not only sell cold drinks, they provide a lifestyle. Despite the fact that Pepsi is preferred in blind-tests and the price is about the same, Coca-Cola is favored by most people. Coca-Cola has a competitive advantage over Pepsi through the Coca-Cola brand. Coca-Cola has through its branding been able to create long-term relationships with its customers and establish a connection between the customers and the brand (Bergström et al., 2010).

The problem is that brands appear to change and develop their "power" in several different ways. There is no single approach to developing a strong brand. Branding logic appears to vary for each individual brand. Coke's brand power is different from Starbucks, even though both are strong brands in the beverage category. While Coke is a long established brand, Starbucks emerged only recently, with a different logic as a retailer and beverage product (Kay, 2006).

Branding does not only inform external stakeholders, such as customers and investors, about the values of the organization, it also potentially instructs and directs organizational members. In this sense, branding can be viewed as a management and leadership practice. Brands and branding activities not primarily as marketing tools, but rather as a way of expressing preferred values and meanings and transferring them to the internal and external audiences. Therefor brand is management of meanings (Kärreman and Rylander, 2008).

Branding is the art of creating and maintaining a brand. Brand must to be compatible to wants and needs of target audiences. Marketers seek to develop or align the expectations comprising the target audience's brand experience through branding activities. Corporate branding aims to modify the image (the perceived-self) and/or to reflect a change in the identity (Singh et al., 2012).

\section{B. Product Branding}

According to the traditional view of product branding, a brand consists of a set of perceptions which serve to differentiate the product from the competition. The brand strength depends on the extent to which these perceptions are consistent, positive and shared by consumers. To improve the brand strength, managers need to shape this set of perceptions so that the target audience will think of the brand in positive terms (McDonald et al., 2001). Effective branding is frequently conceived or categorized in many marketing textbooks under the rubric of a "product decision" within the marketing mix framework. When products or services are initiated and introduced, its brand need to be "designed" - both literally as a design, but also as a symbol having memorable associations and "strong" meanings. The goal, or what can be called one of the "primary logics" of branding, is 
to distinguish or differentiate a product or service within its category. Within this "product decision" framework, branding decisions have certainly been effectively applied to products and services for many decades (Kay, 2006).

Corporate branding refers to the strategy in which brand and corporate name are the same whereas product branding builds separate brand identities for different products (de Chernatony, 1997). The concept of the brand can be traced back to product marketing where the role of branding and brand management has been primarily to create differentiation and preference for a product or service in the mind of the customer. Within this field, there are a number of generally accepted definitions. These variously refer to the brand as "a product or service, which a customer perceives to have distinctive benefits beyond price and functional performance" or "a symbol serving to distinguish the products and services of one company from another" (Knox and Bickerton, 2003).

The managerial rules of branding practices need to be carefully considered. Brands are a type of logical structure or representation, and they acquire power in different ways. Brand managers need to identify the appropriate branding logic. Initially, the "product" logic of branding suggests that brands are created to identify the product, to make it more or less distinctive from other products in the category. Managers perceive the need to establish "difference" as an important initial priority, but this goal may change as brands acquire meaning and strength (Kay, 2006).

Products satisfy some needs of customers but corporate brand can focus on all of customer's needs. Company differentiation cannot be achieved purely through classic economic ingredients such as advertising, sales force effort, changes to product design and product differentiation: it also relies on the brand and the company's value proposition. Therefore, managers must optimize the brand value chain rather than the product value chain (Lassen et al., 2008). From a company perspective, strong product brands are indispensable as they offer source of differentiation, allow charging price premium, increase company value, and lead to customer loyalty which ensures future profits (Üffing, 2009).

\section{Corporate Branding}

Knox and Bickerton (2003) propose a more holistic definition of the corporate brand, "the visual, verbal and behavioral expression of an organization's unique business model". Although corporate names can certainly be easily applied to the branding of a corporation's products and services, corporate names seldom provide satisfactory solutions to the goal of communicating an effective or meaningful message about the brand. While there may be efficiencies in using the corporate name to brand a variety of products, there could are also considerable risks in doing this (Kay, 2006).

Establishing successful corporate brand management practices relies on the identification of two factors. First, the mix of variables that comprise the corporate brand, and second, the development of a brand management system for understanding this process of direction and control (Knox and Bickerton, 2003). Balmer (2001a) states that corporate brands are cultural, as they reflect the organization's sub cultures, intricate in that they are both multidimensional and multidisciplinary and tangible, as they encompass elements such as business scope and architecture. He also points to the ethereal characteristic of corporate brands as they evince emotional responses from stakeholder groups and the need for total commitment across the organization to manage a corporate brand successfully (Balmer, 2001).

In a competitive situation getting the company branding right is perhaps the most important job for management. The companies behind the classic brands are not by any means a good model. That means they are too split by function to lead naturally to the innovation and imagination that any brand constantly needs. Decisions tend to be made too tactically, too low down in the organization, with too little guidance from the top, but the right organization for a company brand implies that brand management should reside right at the top (King, 1991).

Hatch and Schultz (2003) argue that corporate brand engineers interactions among strategic vision, organizational culture and corporate image, to position the firm in its marketplace. Corporate brand building is an ongoing interaction and negotiation of meaning and values in a cultural context between different identities: the identity of the organization, the identity defining the corporate brand, and the identity as perceived by the customers and other stakeholders (Urde, 2009).

Corporate branding can be described as the process of creating, nurturing and sustaining a mutually rewarding relationship between a company and its internal and external stakeholders. Corporate branding is the way in which an organization communicates its identity (Sorensen, 2011).A robust and trusted corporate brand is vital to the success of any organization. Corporate brands are seen as a guarantee of quality, as an insurance against risk of poor performance or financial risk (Roodurmun and Kassean, 2010).

Corporate branding has three main goals: Firstly, it seeks to bring the organization together internally. Secondly, it seeks to harmonize internal and external communication. Under the challenges of greater transparency (to the media, to investors and to other stakeholders) creating consistent messages reduces the 
chances of conflict and increases the profile of the organization. Thirdly, integrated communication aims to enforce a core, enduring and distinctive identity for the organization (Jones, 2010). A corporate brand intends to identify, differentiate and position the organization, based on a single and unified message to build trust in the entire organization. Its source for originality, uniqueness and inimitability is the organization's heritage and the values and beliefs that the corporation and all its stakeholders hold in common (Kaufmann et al., 2012).

The corporate brand was defined as the visual, verbal and behavioral expression of an organization's unique business model and the communication interface between the organization and its stakeholders. Corporate branding, internally, is seen to signal messages about a desired culture and externally to facilitate customers' desires to look deeper into the corporation and, through building respect and trust with the corporation's offerings, to encourage consumers to accept the corporation's promises about other offerings (Shamma, 2012). A corporate brand can be regarded as the sum of the corporation's marketing efforts to present a controlled representation of the corporation's value system and identity. It differs from a product brand in its strategic focus and its implementation, which combines corporate strategy, corporate communications and corporate culture (Balmer, 1995, 2001).

\section{The Synergy Between Product and Corporate Branding}

Strong corporate brands are possible only when firms tie their products or services to activities that create meaningful associations or representations of the firm. Brands have logic and a history that are rooted in their management, brands are not logically perceived to be the same as the companies that created them. The logic of building a strong brand is tied to developing meaning and through distinctive brand associations that customers recognize. Companies cannot leverage their company name if corporate activities are not strongly associated with their products or services. Powerful corporate brands are defined by representative activities and associations that make their organizations visible and notable. In fact, few corporations embody such values (Kay, 2006).

Following the extension of the scope and applications of branding, interactions between the product, the company and the customer are becoming more closely scrutinized by marketing academics and practitioners. The degree of synergy between the corporate brand and the product brand depends on the brand architecture. The various relations can be illustrated along a spectrum from the branded house (corporation and products share the same name) to the house of brands (there is separation between the corporate and product brands), including endorsed brands and sub brands. Most companies employ mixed strategies. The synergies between product and corporate brands are stronger in a branded house situation, as the master brand contributes to the offering by adding associations that enhance the value proposition, reinforcing the credibility, as well increasing visibility and communication efficiencies (Muzellec and Lambkin, 2009).

Degree of synergy between the corporate brand and the product brand depends on the brand architecture. The term brand architecture is sometimes used as a synonym of branding strategy. The concept of brand architecture, which explains how multiple product brands owned by a single company relate to one another, helps some people understand the relationship between a product and a corporate brand (Shahri, 2011).

\section{E. Branding Functions}

Recent studies in the marketing literature make it appear that managers are singularly focused on the goal to build strong brands. Having a notably strong brand is a considerable managerial resource, it can help establish distribution networks, enable brand extensions to aid customer acceptance of new products, and strengthen pricing flexibility. The function of a brand is to create meaning, and there are myriad ways of making meaning happen. Strong brands, moreover, have quite a profound strategic impact; they make customers loyal and less price sensitive. Moreover, when brands are perceived as different, firms avoid direct or head to head Competition (Kay, 2006).

In summary, corporate brands have a utility in several regards: they communicate the brand's values (often seen as a promise), they afford a means of differentiation from their competitors, and they enhance the esteem and loyalty, in which the organization is held by its stakeholder groups (Balmer, 2003). Strong brands can be powerful in specific situations, particularly during times when consumers face uncertainty in choice. Brands are also powerful when consumers are making an initial choice, such as when consumers are young or if consumers are unfamiliar with the product category (Kay, 2006). In the world that products and services are changing fast, corporate brand can be regards as a competitive advantage for organizations. Corporate brand moreover product physical functions encompasses emotional and sensational functions (Balmer, 2010).

Brands are now being used as a focal point in the formulation of corporate strategy. Well-known and strong brands have a huge potential for increasing the ability of companies to compete as well as generating their growth and profitability. Understanding of this immense potential will make brands paramount in the formulation of corporate strategies and as a source of sustained competitive advantage (Mustafa, 2010). To the buyer, brands serve to identify the sources of the product, assign responsibility to the product maker, reduce risk 
and search-cost, signal a promise with the seller or producer and symbolize the product's quality. To the manufacturer, brands are a Means to provide valuable reassurance to business customers who may be putting their company's fate on the line (Kolarova, 2009).

Hatch and Schultz (2003) conclude that firms successful in establishing a corporate brand are more competitive than firms relying only on product branding in the fragmented markets created by globalization. As recent research shows, strong brands can act as important triggers of confidence, satisfaction, and risk reduction for customers. Companies owning strong brands can benefit from higher quality perceptions, better differentiation, higher demand, premium price, and higher customer loyalty, among other advantages (Biedenbach, 2012). The researches show that with regard to annual turnover, firms with lower turnover were found to be less brand-oriented and put less emphasis on brand identity development and internal branding. The results, hence, support the suggestion that successful firms are more brand-oriented (Hirvonen and Laukkanen, 2011).

When a company creates strong brand it attracts customer preference and company is more protected against a competition afford. Strong brands obtain good prices and large market shares through its strong brand management initiatives, and company can plan a growth through the penetration of new markets. In business, having a strong brand can ensure a company's long-term success; companies with portfolios of strong brands create value for the company competitiveness in the market. A brand represents the adding of value to a product; it combines physical and psychological elements. The physical aspect creates the linkage between the brand name and the enterprise or its products, differentiating them from other enterprises or products. The psychological aspect of a brand constitutes the maintenance of uniformity in terms of communications, guarantees and behavior, as well as consistency and conformity to particular requirements (Chovancova, 2012). The resource-based view within the strategy literature has argued that sustainable competitive advantage is created primarily from intangible capabilities, including brands and reputations. It seems that corporate brand and reputation can have four attributes (valuable, rare, imperfectly imitable and non-substitution) of competitiveness advantage (Abratt and Kleyn, 2012).

It can be inferred, corporate brands have a utility in several regards: they communicate the brand's values (often seen as a promise), they afford a means of differentiation from their competitors, and they enhance the esteem and loyalty in which the organization is held by its stakeholder groups. Basically, corporate branding is a manifestation of the features that distinguish an organization from its competitors. It is a reflection of the organization's ability to satisfy consumer's needs namely: trust in the company to deliver a consistent level of product/service, quality of the product/service at a reasonable price and the reduction of risk of making an unwise purchase decision (Roodurmun and Kassean, 2010). Branding benefits are attracting audiences, communication with various stakeholders, making more revenue (because of premium price), establishment of coalition and partnership with strong partners, means to provoke internal changes in organization and help organizations to rediscover their basic purposes and what they are (Stensaker, 2007).

\section{F. The Similarities Between Product and Corporate Branding}

Corporate branding draws on the traditions of product branding in that it shares the same objective of creating differentiation and preference. However, this activity is rendered more complex by managers conducting these practices at the level of the organization, rather than the individual product or service, and the requirement to manage interactions with multiple stakeholder audiences (Knox and Bickerton, 2003). All company names are, to some degree, corporate brands. Certainly, corporate brands can be managed, similar to product brands. Building a strong corporate brand is fundamentally different from building product or service brands. Corporate branding and corporate identity targets are distinct from product and service branding targets (Kay, 2006).

While corporate and product brands are now recognized as distinct entities, they may sometimes be considered as equivalent because they are context independent and share the same objective of creating differentiation and preference. Yet the complexity of the corporate context has fundamental implications for the nature of the corporate brand. Corporate branding goes beyond product branding by ignoring product features and focusing on a well-defined set of values (Muzellec and Lambkin, 2009). Corporate branding has its starting point in the product branding and therefore the two are closely connected (Sorensen, 2011).

Corporate branding builds on the tradition of product branding, seeking to create differentiation and preference. However, corporate branding is conducted at the level of the firm instead of the product or service, and furthermore extends its reach beyond customers to stakeholders such as employees, customers, investors, suppliers, partners, regulators and local communities (Hatch and Schultz, 2001).

\section{G. The Differences Between Product and Corporate Branding}

There are obvious advantages in all aspects of communication to be gained from economies of scale when organization ties a brand name in with its corporate name. There are also very good reasons why in certain 
circumstances it is advisable to follow the individual brand name route. As in the case of Procter \& Gamble this allows the marketer to develop formulation and positioning to appeal to different segments in different markets. However, the economics of this need to be carefully considered, since firms may, on closer analysis, find that by trying to appeal to different small segments through different brand offerings, they are encountering higher marketing costs resulting in reduced brand profitability. Another advantage of using individual brand names is that if the new line should fail the firm would experience less damage to its image than if the new brand had been tied to the corporation (McDonald et al., 2001).

The challenges of corporate branding differ in a number of ways from those relevant to product brands. Companies such as Unilever and Procter and Gamble rely heavily on product branding, where the imagery differs from one brand to another. The corporate name is not promoted strongly to consumers. Others, such as Mars and Nestle, use their corporate name to label individual product brands. Still more, such as Hilton and British Airways have unitary branding strategies where the brand and corporate names is the same (Davies \& Chun, 2002). While product brands may need to appeal to a limited group of stakeholders, those who buy and use the product, corporate brands may need to appeal to a number of, quite separate, groups, including potential employees and suppliers, as well as customers (Davies \& Chun, 2002).

When examining brand names, it is possible to categorize them broadly along a spectrum, with a company name at one end (e.g. British Telecom, Halifax), right the way through to individual brand names which do not have a link with the manufacturer (e.g. Ariel, Dreft, Daz, Bold and Tide emanating from Procter \&Gamble). This is shown in Figure 1.There are varying degrees of company associations with the brand name there are brand names with strong company endorsement, such as Cadbury's Dairy Milk, Castrol GTX, Sainsbury's Baked Beans, and brand names with weak company endorsement, such as Kit Kat from Nestle. There are many advantages to be gained from tying the brand name in with the firm's name (McDonald et al., 2001).

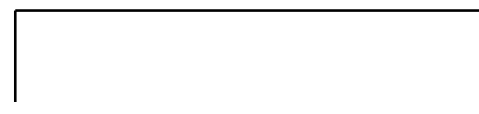

Company as brand name
Strong company endorsement

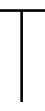

Weak company endorsement
Individual

brand name

\section{Figure 1. Brand name spectrum}

Corporate branding is different to standard product brand activities in three ways. First, the corporate brand is intangible, but receives tangibility through the messages that a company puts out and relationships that it develops with a variety of stakeholders. Secondly, the corporate brand has a high degree of complexity, partly because of these various relationships and messages and partly due to the potential for confusion, through the sectionalism of many corporations. Finally, it is emphasized on the role of people in delivering consistent brand messages and in the corporation having a sense of ethical or social responsibility for corporate brand (Burt and Sparks, 2002).

Balmer and Gray (2003) compare differences corporate and product branding from management, functional, general responsibility, disciplinary roots, brand gestation, stakeholder focus, values, communication channels and dimensions requiring alignment perspectives. Balmer (2001) suggests that corporate brands differ from product brands in higher strategic focus, internal as well as external targets, and incorporation of corporate strategy. As a result, the role of employees - including senior management - is seen as crucially important in transmitting the brand values both internally and externally (Balmer and Gray, 2003).

There is an important distinction between a corporate brand and a product brand. The product brand focuses on the product and the customer; while the marketing activity as a short, long, and tactical function handles it. In contrast, the corporate brand clearly focuses on the whole organization where the CEO has a crucial role and ultimate responsibility for its management. It considers multiple stakeholders as a strategic factor in the organization (Shahri, 2011).

\begin{tabular}{|c|c|c|c|}
\hline \multicolumn{4}{|c|}{ The differences between product and corporate brands } \\
\hline \multicolumn{2}{|r|}{ Items } & Product Brand & Corporate Brand \\
\hline \multicolumn{2}{|r|}{ Focus } & Product & Organization \\
\hline \multicolumn{2}{|c|}{ Management } & Middle Management & Top management \\
\hline \multicolumn{2}{|c|}{ Targeting Segments } & Customers & Variety Stakeholders \\
\hline \multirow{3}{*}{ Responsibility } & Functional & Marketing Department & All Departments \\
\hline & Managerial & Brand Manager & Chief of Executive \\
\hline & General & Marketing Personnel & All of organizational people \\
\hline \multicolumn{2}{|c|}{ Communication Mix } & Marketing communications & Organizational communications \\
\hline \multicolumn{2}{|c|}{ Importance for Organization } & Functional & Strategic \\
\hline
\end{tabular}


The Comparison of Product and Corporate Branding Strategy: a conceptual framework

\begin{tabular}{|c|c|c|}
\hline Time Horizon & Short Time & Middle to Long Time \\
\hline Disciplinary Roots & Marketing & Multi-Disciplinary \\
\hline Flexibility & High & Low \\
\hline Change Agent & Low & High \\
\hline Imitability & High & High \\
\hline Risk & Low & Real \\
\hline Values & Contrived & Strong \\
\hline $\begin{array}{c}\text { Need to organizational cooperation and } \\
\text { integration }\end{array}$ & Poor & High \\
\hline Ethical and Social Issues & Low & High \\
\hline
\end{tabular}

Table 1. The differences between product and corporate brands

\section{A. Branding Strategy}

\section{Conceptual Model}

The role of the brand within the business strategy needs to be established. Should the role of the brand be simply symbolic, the face of a business strategy or is brand integral to and inseparable from the business strategy? Providing an answer to this question is not easy, due to the fragmentation of knowledge domains that contribute towards this. These domains include strategic management, strategic marketing, strategic brand management, relationship marketing and services marketing. Both the inside-out and outside-in approaches has accepted the increasing importance of intangible resources. The brand, through brand equity is widely accepted as the main intangible asset of the firm and hence calls for its careful management. A brand orientation also offers the opportunity to integrate the inside-out and outside-in mindsets, because it implicitly incorporates both (M'zungu et al., 2009).

Branding strategy refers to the ways that firms mix and match their brand's name on their products and a firm, through its products, presents itself to the world. Corporate brand strategy must be developed to deliver the highest gains to all stakeholders and corporate publics (Shahri, 2011). The discussion about market orientation and brand orientation is in essence concerned with a company's or organization's approach to brands and the market. Is it the brand identity or the brand image that serves as a guiding light? Should a company's management primarily take the outside-in (Market orientation) perspective or the inside-out (Brand orientation) perspective when guiding their brands? Or should they select a brand approach that is a combination of these two perspectives? How can management square the general principle that the customer is king with the specific belief that our brands are our greatest assets (Urde et al., 2013)?

Strategic management consists of two interlocking tasks: the task of formulating a strategic plan and the task of implementing and executing the strategic plan. The strategic plan is a detailed blueprint of management's answers to three basic strategic questions (Abratt, 1989):

(i) What will we do and for whom shall we do it?

(ii) What objectives do we want to achieve?

(iii) How are we going to manage the organization's activities so as to achieve the chosen objectives?

Strategic corporate branding decisions can be separated into strategic and operating decisions. Strategic corporate branding decisions involve identifying and maximizing the actual and perceived fit between the organization and its environment. Operating decisions regarding corporate branding include tactical activities that firms use to enhance branding on a day-to-day basis. That is, decisions involving the timing and word choice for an announcement, newsletter, or advertising campaign are tactical corporate branding decisions. Strategic corporate branding is derived from the turbulence or uncertainty in a firm's environment and its internal capabilities to manage these pressures. Dual-acting pressures from the external and internal environments impact corporate brands. Strategic corporate branding implies aligning external pressures and appropriate internal capabilities to effectively manage and inform the multiple constituencies affected (Griffin, 2002).

While the consensus is that every organization needs to develop strong brands as an essential part of their business strategy, therefore design and development of precise means for bringing this is necessary (Kay, 2006). Urde (2003) suppose that organizational values, core values and added values are the foundation of a corporate brand. The interaction among them forms the value-creating process of the corporate brand. He also asserts that there are four basic brand architectures or branding strategies available to firms: corporate, product, corporate-and-product (with dominant use of the corporate brand) and product-and-corporate (with dominant use of product brands).

In general, one can observe that managers operating at the corporate level and those operating at the business unit level disagree about the preferred degree of corporate endorsement. Where corporate level managers advocate a clearly visible presence of the corporate brand, most business unit managers favor a weaker endorsement by the corporate brand. Relatively often, the vision of the corporate managers about the role of the corporate brand does not match with vision of business unit managers. However, for a successful 
endorsement process of the corporate brand, such an agreement between corporate and business unit management is necessary. If top management of a corporation decides that it wants to strengthen the role of the corporate brand in its business units' communication, it is important to understand the drivers of the attitude of business unit management towards the endorsement of this corporate brand. Developing this understanding is the goal of the SIDEC ${ }^{1}$ model (Van Riel and Van Bruggen, 2002).

Over time, formal institutions shape the informal rules by which organizations operate. The relative economic and social stability in developed countries promotes the development and acceptance of rules of exchange. In contrast, the economic and sometimes social instability in emerging markets produces ambiguity and uncertainty regarding the rules of exchange. Additionally, firms from developed countries have longer established repertoires for alliance activity than firms from emerging markets. Also important differences in the underlying institutional infrastructures of emerging and developed markets affect managers' strategic orientations. Finally, in emerging markets, the economic and institutional infrastructures for distributing capital often is not well developed (Hitt et al., 2000).

The SIDEC model explains the willingness of business unit managers to use the corporate brand in business unit communication. Four categories of variables in the model are distinguished that will affect business unit management attitudes towards the corporate brand endorsement level. These categories are: the nature of the corporate strategy (related or unrelated), the internal organization, the degree of centralization in planning and control from the head office with respect to the business units, the homogeneity or heterogeneity of the driving forces, resulting in a higher or lower degree of identification with the company, at both the corporate and the business unit level and the dominant logic regarding the (perceived) external prestige that affects the corporate branding policy (Van Riel and Van Bruggen, 2002). Many multinational companies from developed countries have multiple subsidiaries, together with multiple brands and cultures. The consequent potential for conflicting corporate associations frequently impedes communication between the firm and its stakeholders, resulting in a lack of coherence and difficulties in coordination. Therefore, strong integration of the different internal units is needed for a coherent corporate brand image and favorable corporate reputation (Einwiller and Will, 2002).

Crittenden and Crittenden (2010) asserts that emerging (or developing) countries have some characteristics: very high growth rates in economics about 10 percent, middle-income, liberalization of economic and markets, latecomers to development, lack of proper business structure, laws and rules, political and decisional instability, the constraints of capital and human markets and challenging the economic situation of developed countries for their growth. Their economies have also been growing much faster than those of developed countries. Western consumer markets were seen as approaching saturation. By contrast, the growth rates and general business climate were seen as more favorable in developing countries. All these factors have encouraged established Western brands to bid aggressively for market share in the developing world (Keller and Moorthi, 2003).

\section{B. Conceptual Model}

The brands as strategic assets and resources of competitive advantage for organizations in changing and high competition world need to strategic attention and consideration from them. Strategic management is a bilateral issue, considering organizational strengthens and weakness (internal factors) and environmental opportunities and threats (external factors). Also strategic brand management can be viewed from these two internal (identity) and external (image) perspectives. Establish of balance and alignment between identity and image is one of the most issues in strategic brand management. Therefore, organizations must regarding two main factors namely internal (organization) and external (environment or context of operation and target country or market) factors in the selection and choice of branding strategy.

With regarding and consideration of various models such as Griffin, (2002), McDonald et al., (2001), Urde, (2003), Van Riel and van Bruggen, (2002), Xie and Boggs, (2006) and others models can be reached to a model and guideline to selection and choice of branding strategy for multi business companies operating and entering in emerging or developing markets (economies). The basis of this conceptual model is Xie and Boggs, (2006) paper and indeed, development and extended of their model to multi business companies. Figure 2 demonstrate this conceptual model. The suggested model helps multi business companies from developed countries in choice of branding strategy entering to emerging or developing markets. It is evident that this model can be a proper guidance to individual (single) business companies (from developed economies entering to emerging or developing economies or companies operating in emerging markets) with deletion of a section from it. Figure 2 proposed visualizes that the strength of the relationship between influencing factors and choice of branding strategy is moderated by other situation-dependent influences. We highlight here two major category (organizational characteristics 1,2 ) moderating factors.

${ }^{1}$ - Strategy, Internal Organization, Driving Forces, External Prestige and Corporate Branding Strategy 
Because of broader the stakeholders' interests, the firms operating in emerging markets more likely will choose corporate branding. In emerging markets, there are many different stakeholders that affect organization. In these markets, corporate image is emphasized by stakeholders more and more, therefor entrants from developed countries are to choose corporate branding more likely. Developing economies experience political and legal instabilities daily; as a result, it can be suppose that corporate branding can manage these instabilities and decrease their effects. Because lack of valid and reliable information, media and other communication channels, the marketing costs are very high in developing economies and companies prefer corporate branding strategy.

Market entrants selling industrial products in emerging markets are more likely to use corporate branding than those marketing consumer products. From social and cultural perspective, there are some problems about the consumers' expert level, middle income, suspicious for foreign companies. In these markets, social responsibility is very important and corporate branding is better way. Todays, products are very changing fast. In dynamic and very changing industries, product branding strategy is not feasible from economical viewpoint. Lack of obvious relationships along exchange parties in emerging market lead to complexity with high degree; therefor it seems that corporate branding is proper solution to complexity problem.

If the degree of strategic fit between activities of business unit and parent company is high, then the willingness of business unit to use of the corporate brand will be higher. In multi business companies with high centralized structure, business units' management has more inclination to use of the corporate brand. Business units will have tendency to use corporate brand if the degree of organizational identification with the organization as a whole be high. A high level of perceived external prestige of the corporate brand will result in a willingness of business unit management to use the corporate brand.

Larger size usually implies greater availability of production, financial and management resources. Large firms adopt a market orientation to a greater extent than medium-size firms. Therefore, the size of a firm entering the emerging market is positively associated with the probability of choosing product or corporate branding.

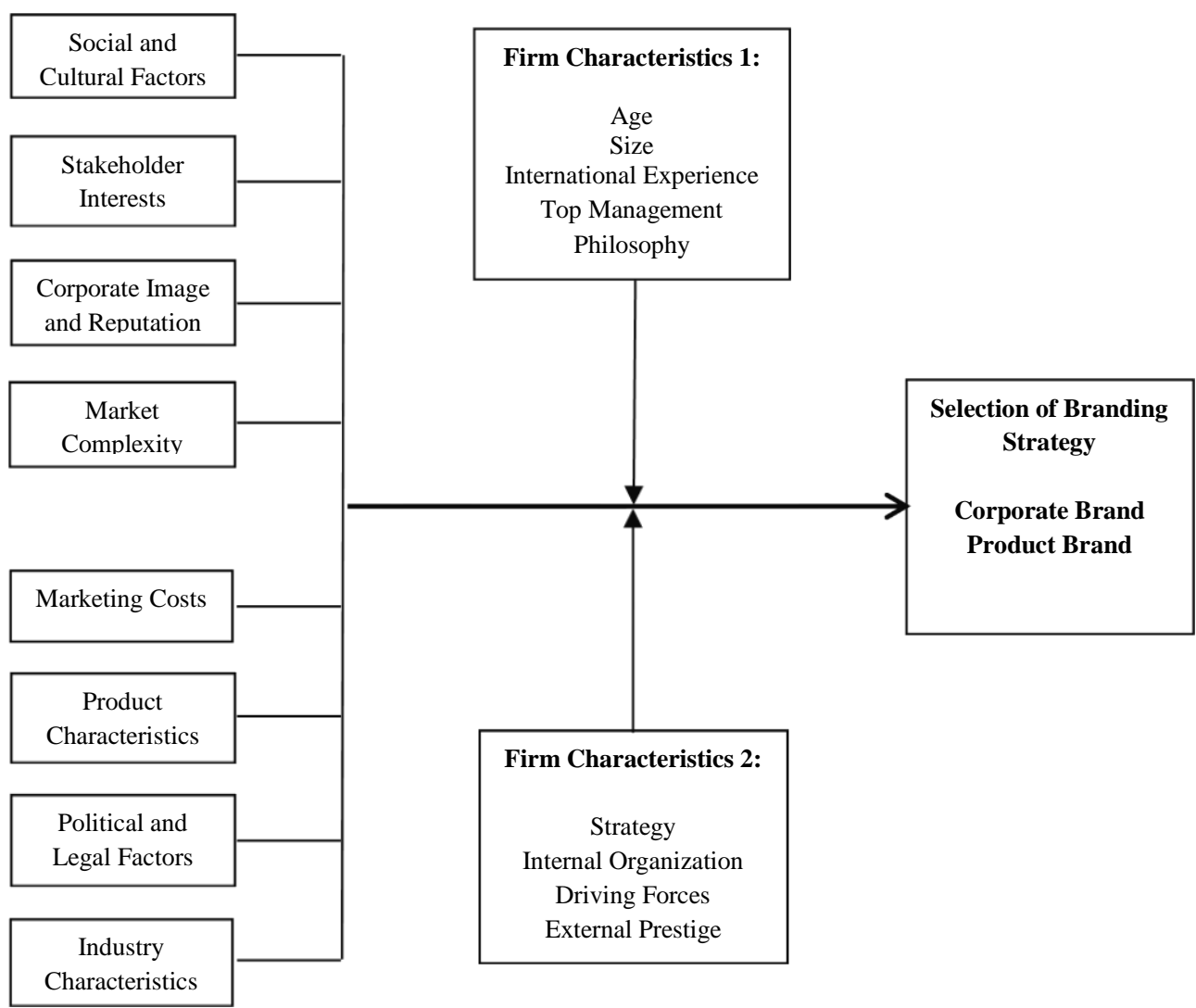

Figure 2. Conceptual model of factors affecting branding strategy selection for multi business companies from developed country entering in emerging or developing markets

Information gathering and analysis about market and customers is important to survival and development firm, especially in product branding. New firms have constraints about this; as a result the length 
of a firm's relevant experience is positively associated with the probability of choosing product or corporate branding. To enter in foreign market international experience plays a critical role. Product branding requires much sophistication on customers' needs and behaviors whereas corporate branding tends to be more general. Management approach and philosophy impact on branding strategy. Managers have different attitudes towards social responsibility of organizations. In corporate branding, firm is responsible about social issues.

\section{Conclusion}

Today, companies in a variety of industries attempt to develop strong brands and to use them for achieving success in the competitive marketing environment. It is vital to be different in the crowded market so that the brand will not easily forgotten by the customer. Organizations use corporate branding, product branding strategies or mix of them to meet needs and expectations of customers or other stakeholders in different conditions of economical, social, legal, cultural and etc. Understanding of branding principles, product and corporate branding, differences and similarities between them and factors (internally and externally) affect branding strategy is important in the choice of proper branding strategy.

Choice and selection of branding strategy as a strategic decision need to precise study and sufficient information. In this decision making must regarding internal conditions of organization and environmental conditions. Although there is not the best branding strategy, but the best branding strategy depends on conditions. At first point as a conclusion, it cannot be stated that corporate branding is better or product branding, but studies indicate that there is a tendency and trend towards corporate branding strategy in organizations. It can be reached the best choice of branding strategy with precise study of market circumstances and organizational factors.

\section{Suggestions for Future Research}

It is recommended that future researchers can investigate each of factors affecting branding strategy separately and related with others. Also, this research can be done in different countries and industries and compare differences between them. We are preparing a paper that we will study these factors in detail and testing them in Iran market empirically. Future researchers also can attempt to replicate this study in other service industries and compare the results thereof future studies. It would be desirable to conduct more in-depth and in-breadth research in the related research topics and to enrich the literature on this theory of competitive advantage in progress.

\section{References}

[1] Abratt, R. (1989), "A new approach to the corporate image management process", Journal of Marketing Management, Vol.5, No.1, pp.63-76.

[2] Abratt, R. and Kleyn, N. (2012), “Corporate Identity, Corporate Branding and Corporate Reputations: Reconciliation and Integration", European Journal of Marketing, Vol. 46, Issue. 7/8, pp. 1048-1063.

[3] Balmer, J.M.T. (1995), "Corporate branding and connoisseurship", Journal of General Management, Vol. 21, No. 1, pp. 9-19.

[4] Balmer, J.M.T. (2001), "The three virtues and seven deadly sins of corporate brand management", Journal of General Management, Vol. 27, No. 1, pp. 1-17.

[5] Balmer, J.M.T. (2001a), "Corporate identity, corporate branding and corporate marketing", European Journal of Marketing, Vol. 35, No. 3/4, pp. 248-291.

[6] Balmer, J.M.T. (2010), "Explicating Corporate Brands and Their Management: Reflections and Directions From 1995", the Journal of Brand Management, Vol. 18, No. 3, pp.180-196.

[7] Balmer, J.M.T. and Gray, E.R. (2003), "Corporate brands: what are they? What of them?" European Journal of Marketing, Vol. 37, No. 7/8, pp. 972-97.

[8] Balmer, J. M. T. And Thomson, I. (2009), "The shared management and ownership of corporate brands: the case of Hilton", Journal of General Management, Vol. 34, No. 4, pp. 15-37.

[9] Bergström, K., Landgren, J. and Müntzing, F. (2010), "Brand Management: A qualitative study on branding in a SME”, Jonkoping International Business School, Sweden.

[10] Biedenbach, G. (2012), "Brand Building in the Business-to Business Context: The Brand Equity Perspective", PhD Thesis, Umea University, Sweden, www.diva-portal.org/smash/get/.../Fulltext01.

[11] Burt, S.L. and Sparks, L. (2002), "Corporate branding, retailing and retail internationalization", Corporate Reputation Review, Vol.5, No2/3, pp. 194-212.

[12] Chovancova, M. (2012), "Building A Strong Brand To SupportCompany Competitiveness", www.sbc.org.pl.content/50647.

[13] Crittenden, V.L. and Crittenden, W.F. (2010), "Strategic management in emerging economies: a research agenda", Organizations and Markets in Emerging Economies, 2010, Vol. 1, No. 1, pp. 9-23.

[14] Davies, G. and Chun, R. (2002), "Gaps between the internal and external perceptions of the corporate brand", Corporate Reputation Review, Vol. 5, No. 2/3, pp. 144-58.

[15] De Chernatony, L. (1997), "Integrated brand building using brand taxonomies", Journal of Product \& Brand Management, Vol. 6, No. 1, pp. 56-63.

[16] Einwiller, S. and Will, M. (2002), "Towards an integrated approach to corporate branding - an empirical study", Corporate Communications, Vol. 7, No. 2, pp. 100-9.

[17] Griffin, J.J. (2002), "To brand or not to brand? Trade-offs in corporate branding decisions", Corporate Reputation Review, Vol. 5, No. $2 / 3$, pp. $228-40$

[18] Handaria, A. and Iskandar, B. P. (2012), "The Practice of Brand Management on Small Culinary Enterprises, An Explorative Study Using in Depth Interview", Journal of Business and Management, Vol. 1, No. 4, pp.300-305. 
[19] Harris, F. and de Chernatony, L. (2001), "Corporate branding and corporate brand performance", European Journal of Marketing, Vol. 35, No. 3/4, pp. 441-56.

[20] Hatch, M.J. and Schultz, M. (2001), “Are the strategic stars aligned for your corporate brand?”, Harvard Business Review, February.

[21] Hatch, M.J. and Schultz, M. (2003), "Bringing the corporation into corporate branding”, European Journal of Marketing, Vol. 37, No 7/8, pp. 1041-63.

[22] Hirvonen, S. and Laukkanen, T. (2011), "Branding in Small Firms: Are All SMEs Similar?", University of Eastern Finland, www.anzmac.org/conference/2011.

[23] Hitt, M.A., Levitas, E., Arregle, J. and Borza, A. (2000), "Partner selection in emerging and Developed market contexts: resourcebased and organizational learning perspectives", Academy of Management Journal, Vol. 43, No. 3, pp. 449-67.

[24] Jones, R. (2010), “Corporate Branding: The Role of Vision in Implementing the Corporate Brand", Innovative Marketing, Volume 6, Issue 1, pp. 44-57.

[25] Kärreman, D. and Rylander, A. (2008), "Managing Meaning through Branding: the Case of a Consulting Firm", Organization Studies, Vol. 29, No. 1, pp.103-125.

[26] Kaumann, H. R., Vrontis, D., Czinkota, M. and Hadiono, A. (2012), "Corporate Branding and Transformational Leadership in Turbulent Times", Journal of Product \& Brand Management, Vol. 21, No. 3, pp. 192-204.

[27] Kay, J.M. (2006), "Strong brands and corporate brands", European Journal of Marketing, Vol. 40, No 7/8, pp. 742-760.

[28] Keller, K.L. and Moorthi, Y. L. R. (2003), "Branding in developing markets", Business Horizons, vol. 46, issue. 3, pp. 49-59.

[29] King, S. (1991), "Brand building in the 1990s", Journal of Marketing Management, Vol. 7, No. 1,pp. 3-13.

[30] Knox, S. and Bickerton, D. (2003), "The six conventions of corporate branding", European Journal of Marketing, Vol. 37, No 7/8, pp. 998-1016.

[31] Kolarova, E. S. (2009), "Brand Association Transfers Between Corporate and Product Building Material Brands: Perceptions of Home Builders", Forest Products Journal, Vol. 59, No. 11/12, pp. 75-82.

[32] Lassen, P., Kunde, J. and Gioia, C. (2008), "Creating a Clearly Differentiated SME Brand Profile: The Case of Montana A / S", the Journal of Brand Management, Vol. 16, No. 1/2, pp. 92-104.

[33] Malik, M. E, Naeem, B. and Munawar, M. (2012), "Brand Image: Past, Present and Future", Journal of Basic and Applied Scientific Research, Vol. 2, No. 12.

[34] McDonald, M., de Chernatony, L. and Harris, F. (2001), "Corporate marketing and service brands- moving beyond the fast-moving consumer goods model", European Journal of Marketing, Vol. 35, No 3/4, pp. 335-46.

[35] Mustafa, B.K. (2010), "Corporate brand management: past, present and future", the Journal of Management Awareness, Vol. 12, Issue 1, pp. 21-39.

[36] Muzellec, L. and Lambkin, M.C. (2009), "Corporate branding and brand architecture: a conceptual framework", Marketing Theory, Vol. 9, No. 1, pp. 39-54.

[37] M'zungu, S., Merrilees, B. and Miller, D. (2009), "Integrating Firm Strategy and Brand Management through Brand Orientation", www.duplication.net.au/anzmac09/papers/anzmac2009-157.pdf.

[38] Roodurmun, J. and Kassean, H. (2010), "The Power of Corporate Branding in Enhancing Brand Loyalty - The Case of Mauritius Telecom Service Provider", International Research Symposium in Service Management, www.uom.ac.mu/sites/irssm/papers.

[39] Ropo, J. P. (2009), "Brand Management and Branding: Creating a Brand Strategy for AD code", Final Thesis Report, University of Applied Sciences, Helsinki, Finland.

[40] Shahri, M. H., (2011), "The Effectiveness of Corporate Branding Strategy in Multi-Business Companies", Australian Journal of Business and Management Research, Vol. 1, No. 6, pp.51-59.

[41] Shamma, H. M. (2012), "Toward a Comprehensive Understanding of Corporate Reputation: Concept, Measurement and Implications", International Journal of Business and Management, Vol. 7, No. 16, pp. 151-169.

[42] Singh, A. K., Tripathi, V. and Yadav, P. (2012), "Rebranding and Organizational Performance-Some Issues of Relevance", American Journal of Sociological Research, Vol. 2, No. 5, pp. 90-97.

[43] Sorensen, L. B. (2011), "Corporate brand strength: Building a strong corporate vision and image through the corporate executive brand", Copenhagen Business School, www.studenttheses.cbs.dk/bitstream/handle/10417/2938/lisa_benn_soerensen.pdf.

[44] Stensaker, B. (2007), "The Relationship between Branding and Organizational Change", Higher Education Management and Policy, Vol. 19, No. 1, pp. 1-17.

[45] Urde, M. (2003), "Core value-based corporate brand building”, European Journal of Marketing, Vol. 37, No. 7/8, pp.1017-1039.

[46] Urde, M. (2009), "Uncovering the corporate brand's core values", Management Decision, Vol. 47, No. 4, pp.616-638.

[47] Urde, M., Baumgarth, C. and Merrilees, B. (2013), "Brand orientation and market orientation -From alternatives to synergy", Journal of Business Research, vol. 66, pp. 13-20.

[48] Üffing, C. (2009), "The Brand Scorecard - An Essential Tool to Manage Brands", HAN Business Publications, Number. 1, pp. 105110.

[49] Van Riel, C.S. and van Bruggen, G.H. (2002), "Incorporating business unit managers 'perspectives in corporate branding strategy decision making", Corporate Reputation Review, Vol. 5, No 2/3, pp. 241-51.

[50] Ward, M.R. and Lee, M.J. (2000), "Internet shopping, consumer search and product branding", The Journal of Product \& Brand Management, Vol. 9, No. 1, pp. 6-15.

[51] Xie, Y. H. and Boggs, J.D. (2006), "Corporate branding vs. product branding in emerging markets, a conceptual framework", Marketing Intelligence \& Planning, Vol. 24, No. 4, pp. 347-364. 